\title{
Pengaruh Ekstrak Kunyit (Curcuma domestica Val) Terhadap Berat Badan, Jumlah Eosinofil dan Basofil Ayam Petelur yang Diinfeksi Salmonella pullorum
}

\section{Effect of Curcuma domestica Val Extract on Body Weight, Total of Eosinofils and Basofils in Laying Hens Infected with Salmonella pullorum}

\author{
Nurul Hidayah ${ }^{1 *}$, Reina Puspita ${ }^{1}$, Mujahidah ${ }^{2}$ \\ ${ }^{1}$ Departemen Mikrobiologi, ${ }^{2}$ Pendidikan Dokter Hewan, Fakultas Kedokteran Hewan, \\ Universitas Wijaya Kusuma Surabaya \\ *Corresponding author: nurulhidayah78@uwks.ac.id
}

\begin{abstract}
Abstrak
Penelitian ini bertujuan untuk mengetahui pengaruh pemberian ekstrak kunyit terhadap berat badan, jumlah eosinofil dan basofil pada ayam petelur dengan infeksi Salmonella pullorum. Sebanyak 28 ekor ayam petelur, dengan 4 perlakuan, yaitu P0 (kontrol), P1 (40\% ekstrak kunyit), P2 (50\% ekstrak kunyit), P3 (60\% ekstrak kunyit). Masa adaptasi DOC selama 7 hari, pada hari ke-8 hingga ke-26 ayam diberi perlakukan. Pemberian ekstrak kunyit secara per oral satu kali sehari dengan dosis $0.1 \mathrm{ml}$ per ekor. Proses pengambilan darah dilakukan pada hari ke-21. Analis statistik menggunakan Anova, menunjukkan tidak ada perbedaan yang nyata $(p>0.05)$ terhadap berat badan ayam maupun terhadap peningkatan eosinofil dan basofil, namun dilihat dari data kenaikan, pemberian ekstrak kunyit dengan konsentrasi 50\% paling bagus dalam meningkatkan berat badan ayam petelur dan pada konsentrasi $60 \%$ paling banyak terjadi peningkatan eosinofil dan basofil. Kesimpulan dari penelitian ini adalah ekstrak kunyit dapat digunakan sebagai imunostimulan pada ayam petelur.
\end{abstract}

Kata kunci: basofil, berat badan, Curcuma domestica Val, eosinofil, Salmonella pullorum

\begin{abstract}
This study aimed to determine the effect of Curcuma domestica Val extract on body weight, Total of eosinophils and basophils in laying hens with Salmonella pullorum infection. A total of 28 laying hens devided into 4 treatment, PO (control), P1 (40\% turmeric extract), P2 (50\% turmeric extract), P3 (60\% turmeric extract). DOC adaptation period for 7 days, of treatment was done at 8 to 26. Administration of oral extracts once daily with a dose of $0.1 \mathrm{ml}$ per head. Blood collection was done on the 21 st day. Statistical analysis used Anova, showed no significant difference ( $p>0.05$ ) on body weight and to increase of eosinophils and basophils, however it was seen from the increase data, Curcuma domestica Val extract with the best $50 \%$ concentration in increasing the weight of laying hens and at the highest were 60\% concentrations of eosinophils and basophils. The conclusion of this research was Curcuma domestica Val extract can be used as immunostimulant in laying hens.
\end{abstract}

Keywords: basophils, body weight, Curcuma domestica Val, eosinophils, Salmonella pullorum

\section{PENDAHULUAN}

Salmonellosis merupakan penyakit bakteri yang sangat strategis pada unggas karena memberikan dampak terhadap perekonomian (Bidhendi et al., 2015). Salmonellosis salah satunya menyebabkan penyakit Pullorum atau berak kapur yang penyebarannya sangat luas hampir di seluruh dunia (Rahman et al., 2016).
Penyakit pullorum menyebabkan penurunan produksi telur, daya tetas menurun serta mortalitas yang tinggi (Selvam et al., 2010). Salmonellosis sampai saat ini masih menjadi masalah serius pada usaha atau industri perunggasan dan termasuk dalam Food Borne Diseases yang bersifat zoonosis (OIE, 2012).

Pencegahan umumnya dilakukan dengan menggunakan vaksinasi dan antibiotik, vaksin 
inaktif memang dapat meningkatkan kekebalan humoral tetapi tidak secara signifikan mengurangi kejadian Salmonella di peternakan (Revolledo, 2012), sedangkan pemberian antibiotika dapat memberikan dampak negatif pada ternak dengan ditemukannya residu antibiotik pada karkas ternak yang dikonsumsi manusia (Purwanti et al., 2014). Pemanfaatan tanaman herbal yang memiliki efek imunostimulan diharapkan dapat meningkatkan kekebalan dalam melawan penyakit.

Kunyit memiliki potensi yang sangat besar dalam upaya pencegahan Salmonellosis. Kurkumin dalam kunyit menunjukkan khasiatnya sebagai antiinflamasi, antikarsinogenik, antibakterial dan fungal serta memiliki peran yang penting dalam memodulasi imunitas (Hewlings et al., 2017). Curcuminoids memiliki aktivitas antioksidan kuat, yang telah dievaluasi secara in vitro maupun in vivo. GuilGuerrero et al. (2017) telah menguji Fraksi polar dari Curcuma longa sebagai imunomodulator pada darah perifer dan dapat disimpulkan bahwa kurkuminoid dan polisakarida dapat digunakan sebagai suplemen adjuvant yang berpotensi pada sistem kekebalan tubuh yang lemah.

Penelitian yang dilakukan oleh Widhowati et al. (2017) juga menunjukkan bahwa pemberian kunyit sebagai suplemen makanan untuk ayam petelur telah meningkatkan jumlah heterofil dan basofil serta berefek imunostimulan terhadap vaksin flu burung. Kurkuminoid memodulasi sistem imun dengan meningkatkan poliferasi sel yang berperan dalam imunitas yaitu sel leukosit. Penelitian ini bertujuan mengetahui pengaruh ekstrak kunyit terhadap eosinofil dan basofil serta pengaruhnya terhadap berat badan ayam petelur yang diinfeksi Salmonella pullorum.

\section{METODE PENELITIAN}

\section{Etika Penggunaan Hewan Coba}

Penelitian ini menggunakan uji ethical clearance Nomor: 254/KKEPK.FKG/X/2016.

\section{Alat dan Bahan}

Materi yang digunakan Day Old Chicken (DOC) ayam petelur strain CP 909, pakan untuk
Starter hi-pro-vite ${ }^{\circledR} 511$ B POKHPHAN, suspensi isolat lapangan $S$. pullorum sesuai standart MaC Farland, ekstrak kunyit dengan konsentrasi 40\%, 50\% dan 60\%, oil emersi, air minum, methanol absolute dan Giemsa 5\% (untuk pewarnaan preparat hapusan darah). Peralatan yang digunakan meliputi: kandang baterai, cooler bag, spuit $3 \mathrm{cc}$, mikroskop binokuler, tabung EDTA, timbangan digital dan object glass.

\section{Ekstraksi Kunyit}

Pembuatan ekstrak kunyit menggunakan metode maserasi, dimulai dengan proses pengirisan kunyit. Kemudian dijemur dan di oven, setelah kering lalu dihaluskan sehingga menjadi serbuk kunyit. Hasil serbuk ditambahkan etanol $96 \%$ dengan perbandingan 1:3 dan dikocok setiap 1 jam sekali selama 48 jam. Tahap selanjutnya adalah penyaringan. Kemudian proses evaporasi hingga diperoleh ekstrak. Pembuatan konsentrasi $40 \%$ dengan cara mencampurkan 40 gram esktrak kunyit dengan $60 \mathrm{ml}$ aquades steril sehingga diperoleh cairan total $100 \mathrm{ml}$, konsentrasi $50 \%$ dengan cara mencampurkan 50 gram ekstrak dengan $50 \mathrm{ml}$ aquades steril demikian juga dengan konsentrasi $60 \%$ dengan cara mencampurkan 60 gram ekstrak dengan $40 \mathrm{ml}$ aquades steril.

\section{Isolasi $S$. pullorum}

Tahapan berikutnya menemukan isolat positif Salmonella dari ayam yang menderita pullorum. Hewan yang mengalami gejala berak kapur di ambil fesesnya, kemudian dari sampel feses tersebut dilakukan isolasi pada media Salmonella Shigella Agar (SSA). Setelah inkubasi 24 jam terlihat koloni berwarna transparan dengan bintik kehitaman di tengah. Koloni bakteri yang positif pada media SSA dilakukan pewarnaan gram untuk melihat morfologi secara mikroskopis yaitu batang dengan susunan berpencar, koloni juga ditanam pada media Triple Sugar Iron Agar (TSIA) dengan hasil bakteri memproduksi gas dan $\mathrm{H}_{2} \mathrm{~S}$ dan tidak memfermentasi laktosa. Tahapan selanjutnya, koloni bakteri yang telah mengalami pengujian dilakukan standarisasi menggunakan 
MacFarland sehingga kita dapat memastikan jumlah koloni per infeksi yaitu $1 \times 10^{8} \mathrm{CFU}$.

\section{Perlakuan}

Metode penelitian ini meliputi, DOC sebanyak 28 ekor dibagi menjadi empat perlakuan yaitu P0 sebagai kontrol, hanya diberi suspensi $S$. pullorum, P1 dengan infeksi pullorum dan ekstrak kunyit 40\%, P2 dengan infeksi pullorum dan ekstrak kunyit 50\% dan P3 dengan infeksi $S$. pullorum dan pemberian ekstrak kunyit $60 \%$, masing-masing perlakuan dengan tujuh ulangan. Adaptasi hewan coba dilakukan selama satu minggu mulai dari DOC berumur 1-7 hari, pada usia 8-26 hari diberikan ekstrak kunyit. Pakan dan minum diberikan secara ad libitum. Proses infeksi pullorum pada usia ke 21. Pengambilan sampel darah dilakukan saat ayam berumur 26 hari dimana ayam sudah menunjukkan gejala berak kapur. Darah yang diambil digunakan untuk perhitungan sel eosinofil dan basofil. Parameter berat badan dilakukan dengan cara menimbang ayam pada usia 1 hari, 7 hari, 20 hari, 25 hari.

\section{Analisis Data}

Data yang diperoleh dari hasil pemeriksaan jumlah eosinofil dan basofil disajikan dalam bentuk deskriptif dan di analisa menggunakan uji Anova dengan taraf kepercayaan $\alpha=0,05$.

\section{HASIL DAN PEMBAHASAN}

\section{Pengaruh Ekstrak Kunyit pada Berat Badan}

Hasil penelitian pengaruh ekstrak kunyit terhadap berat badan disajikan pada Tabel 1 . Pada kelompok perlakuan yang diberikan ekstrak kunyit 40\% (P1), 50\% (P2) dan 60\% (P3) terdapat perbedaan yang tidak signifikan dengan kelompok P0 kontrol dengan nilai rerata berat badan ayam $p>0,05$. Perbedaan yang tidak signifikan tersebut salah satunya karena pengaruh dari cara pemberian ekstrak kunyit secara peroral.

Penelitian yang dilakukan oleh Shahani et al. (2010) menunjukkan bahwa kurkumin menunjukkan bioavailabilitas yang kurang optimal ketika diberikan secara peroral, karena degradasi kurkumin yang cepat dan penyerapan yang kurang baik pada saluran pencernaan, sehingga menghasilkan konsentrasi plasma yang rendah dan distribusi rendah dalam jaringan. Kurkumin dalam tubuh diubah menjadi dihidrokurkumin (DHC), tetrahydrocurcumin (THC), hexahydrocurcumin (HHC), dan octahydrocurcumin dengan aktivitas reduktase dan lebih lanjut terurai menjadi $\beta$ glucuronidase dihydrocurcumin-glucuronide dan tetrahydrocurcumin -glucuronide. Formulasi yang berbeda dari kurkumin perlu diuji untuk memaksimalkan efeknya. Pemberian kurkumin umumnya dilakukan secara peroral, namun demikian pemberian secara subkutan juga perlu dibuktikan pengaruhnya.

Hasil penelitian secara statistik menunjukkan tidak ada perbedaan yang nyata, pemberian ekstrak kunyit pada berbagai konsentrasi dapat mempengaruhi pertumbuhan berat badan ayam dibandingkan dengan kelompok kontrol yang hanya di beri perlakuan infeksi Salmonella tanpa diberi ekstrak kunyit. Jovicic et al. (2017) menyebutkan bahwa Kurkumin sering digunakan sebagai aditif makanan karena kurkumin sangat stabil, kurkumin relatif inert terhadap reaksi dengan bahan lain (dapat membentuk garam dengan phthalates dan sitrat), dan inert dalam reaksi dengan fosfat, klorida, dan bikarbonat. Manfaat kurkumin selain sebagai pewarna makanan, juga sebagai antioksidan. Kurkumin mengikat radikal bebas, sehingga menjadi berumur pendek serta tidak reaktif.

Penelitian yang dilakukan oleh Aggarwal and Harikumar (2009) memberikan hasil bahwa kunyit berpengaruh terhadap kenaikan konsumsi pakan ayam dikarenakan pengaruh pemberian kunyit dengan dosis yang telah ditentukan untuk masing- masing perlakuan mempengaruhi terjadinya peningkatan produktivitas ayam petelur dengan kondisi yang optimal. Winarto (2003) juga menyebutkan di bidang peternakan, kunyit dimanfaatkan untuk menambah cerah atau warna kuning kemerahan pada kuning telur. Kunyit jika dicampurkan pada ransum ayam, dapat menghilangkan bau kotoran ayam dan menambah berat badan ayam. 
Tabel 1. Data rata-rata berat badan hari ke 1, 7, 20 dan 25

\begin{tabular}{ccccc}
\hline Periode & P0 & P1 & P2 & P3 \\
\hline Hari-1 & $35.00 \pm 0.82$ & $34.29 \pm 1.11$ & $35.14 \pm 1.57$ & $36.29 \pm 1.38$ \\
Hari-7 & $77.00 \pm 4.24$ & $81.57 \pm 6.29$ & $83.14 \pm 3.02$ & $79.00 \pm 4.55$ \\
Hari 20 & $210.00 \pm 14.26$ & $221.14 \pm 12.55$ & $234.29 \pm 14.76$ & $219.86 \pm 15.59$ \\
Hari-25 & $274.71 \pm 22.46$ & $293.71 \pm 17.19$ & $300.71 \pm 21.93$ & $294.43 \pm 27.52$ \\
Rata-rata & $149.18 \pm 99.68^{\mathrm{a}}$ & $157.68 \pm 106.78^{\mathrm{a}}$ & $163.32 \pm 110.83^{\mathrm{a}}$ & $157.39 \pm 107.25^{\mathrm{a}}$ \\
\hline
\end{tabular}

Superskrip sama pada baris yang sama menunjukkan tidak berbeda nyata $(p>0.05)$

Tabel 2. Data rata-rata jumlah eosinofil dan basofil

\begin{tabular}{ccl}
\hline \multirow{2}{*}{ Perlakuan } & \multicolumn{2}{c}{ Rata-rata \pm SD } \\
\cline { 2 - 3 } & Eosinofil & Basofil \\
\hline P0 & $29.71 \pm 3.64^{\mathrm{a}}$ & $1.57 \pm 0.98^{\mathrm{a}}$ \\
P1 & $29.71 \pm 3.64^{\mathrm{a}}$ & $1.71 \pm 0.76^{\mathrm{a}}$ \\
P2 & $31.43 \pm 3.21^{\mathrm{a}}$ & $1.86 \pm 0.89^{\mathrm{a}}$ \\
P3 & $32.71 \pm 4.75^{\mathrm{a}}$ & $2.14 \pm 1.35^{\mathrm{a}}$ \\
\hline
\end{tabular}

Superskrip sama pada kolom yang sama menunjukkan tidak berbeda nyata $(p>0.05)$

\section{Pengaruh Ekstrak Kunyit pada Eosinofil}

Berdasarkan hasil analisa data, perbedaan rata-rata antara perlakuan $\mathrm{P} 0, \mathrm{P} 1, \mathrm{P} 2, \mathrm{P} 3$ menunjukkan bahwa tidak ada pengaruh nyata terhadap jumlah eosinofil pada ayam petelur setelah diinfeksi $S$. pullorum ( $>0.05$ ) (Tabel 2).

Penelitian Nirmala et al. (2018) menunjukkan bahwa penggunaan serbuk kunyit pada pakan minggu ke 7 dan minggu ke 11 tidak mempengaruhi jumlah eosinofil pada itik lokal. Penggunaan serbuk kunyit dalam pakan dapat mengurangi jumlah eosinofil itik. Eosinofil diproduksi ketika terdapat reaksi alergi, pada saat reaksi alergi sel mast dan basofil mengeluarkan faktor chemotactic eosinofil, sehingga eosinofil bermigrasi ke jaringan yang mengalami radang.

Kurkumin pada kunyit bersifat sebagai antiinflamasi. Target aktivitas anti-inflamasi kurkumin yaitu pada kemampuannya untuk menghambat aktifasi NF- $\mathrm{KB}$ yang merupakan pusat untuk memodulasi sel agar menjadi aktif pada proses inflamasi akut (Cundell and Wilkinson, 2014). Zat anti-inflamasi yang terdapat pada kunyit menyebabkan produksi eosinofil dapat berkurang.

Hasil uji statistik menunjukkan tidak ada perbedaan nyata, rata- rata perhitungan sel darah terlihat adanya peningkatan jumlah eosinofil jika dibandingkan dengan jumlah normal. Jumlah eosinofil dalam sirkulasi darah ayam secara normal sangat sedikit, yaitu berkisar antara 0-7\%
(Frandson, 2009). Jika dilihat dari rata-rata yang diperoleh, menunjukkan adanya peningkatan lebih tinggi pada kelompok P3.

Penyebab peningkatan jumlah eosinofil yaitu adanya senyawa kurkumin dalam kunyit yang bersifat sebagai immunostimulan dengan meningkatkan aktifitas fagositosis dimana dalam hal ini fungsi dari eosinofil adalah detoksifikasi, baik terhadap protein asing yang masuk ke dalam tubuh melalui paru-paru ataupun saluran cerna, maupun racun yang dihasilkan oleh bakteri dan jumlahnya akan terus meningkat (Purnomo, 2015).

Kandungan kunyit yang mempengaruhi jumlah leukosit yaitu kurkuminoid, berfungsi sebagai imunostimulan sehingga menyebabkan peningkatan jumlah leukosit dalam sirkulasi. Peningkatan jumlah eosinofil antar perlakuan yang tidak terlalu berbeda dapat disebabkan oleh salah satu senyawa kurkumioid pada kunyit yaitu bisdesmetoxykurkumin dimana sifat senyawa tersebut bersifat antagonis dengan aktivitas kerja kurkumin dan desmetoxykurkumin menyebabkan adanya hambatan dalam proses penyerapan kurkumin sehingga penyerapan tidak maksimal (Afifah dan Lentera, 2003).

\section{Pengaruh Ekstrak Kunyit pada Basofil}

Hasil pemeriksaan jumlah sel basofil setelah diinfeksi menunjukkan tidak ada perbedaan nyata $(p>0.05) \quad($ Tabel 2). Kelompok P3 mengalami peningkatan jumlah basofil jika 
dibandingkan dengan kelompok perlakuan lainnya. Peningkatan jumlah basofil merupakan indikasi adanya peradangan akut yang menyebabkan hipersensitivitas dan adanya infeksi saluran pernapasan dan kerusakan jaringan yang hebat. Basofil mempunyai fungsi yang sama dengan sel mast yaitu membangkitkan proses perdarahan akut pada tempat deposisi antigen (Rustam et al., 2007). Abbas (2007) menyatakan bahwa heparin akan dilepaskan oleh basofil ke dalam darah untuk mencegah koagulasi pada bagian peradangan.

\section{KESIMPULAN}

Dapat disimpulkan bahwa ekstrak kunyit dapat digunakan sebagai imunostimulan. Pemberian ekstrak kunyit konsentrasi 50\% paling bagus dalam meningkatkan berat badan ayam petelur dengan infeksi pullorum. Peningkatan jumlah eosinofil dan basofil optimal diperoleh dengan pemberian ekstrak kunyit konsentrasi $60 \%$.

\section{UCAPAN TERIMA KASIH}

Penulis mengucapkan terimakasih kepada RISTEKDIKTI atas pemberian dana hibah penelitian skim Penelitian Dosen Pemula (PDP 2016) dan Departemen Mikrobiologi Fakultas Kedokteran Hewan, Universitas Wijaya Kusuma Surabaya sehingga bisa terlaksana penelitian ini.

\section{DAFTAR PUSTAKA}

Abbas, A.K., Lichtman, A.H., Pober, J.S. 2007. Cellular and Molecular Immunology. $6^{\text {th }}$ ed.Pennysylvania: WB Saunders Co, pp: 4771.

Afifah, E., Lentera T. 2003. Khasiat dan Manfaat Temulawak. Rimpang Penyembuh Aneka Penyakit. Jakarta: Agromedia Pustaka, Hal: 5-12.

Aggarwal, B. B., Harikumar, K.B. 2009. Potential Therapeutic Effect of Curcumin, The Anti-inflamatory Agent, Againts
Neurodegenerative, Cardiovaskular, Pulmonary, Metabolic, Autoimmune and Neoplastic Disease. Int. J. Biochem. Cell. Bio., 41, 40-59.

Bidhendi, M., Khaki, P.S., Cheraghchi, N. 2015. Study on Phenotypic Characteristics of Salmonella gallinarum and Sallmonella pullorum isolates based on biochemical and antimicrobial susceptibility tests in Iran. J. Arch. Razi Inst., 70, 171-177.

Cundell, D.R., Wilkinson, F. 2014. Curcumin: powerful imunomodulator from turmeric. Curr. Immunol. Rev., 10, 122-132.

Frandson, R.D. 2009. Anatomy and Physiology of Farm Animals. $7^{\text {th }}$ revised edn. Lowa: Wiley- Blackwell, pp: 257-269.

Guil-Guerrero, J.L., Ramos, L., Paredes, J.C.Z., Moreno, C., Ruales, P. 2017. Effect of turmeric rhizome powder and curcumin on poultry production. J. Anim. Feed Sci., 26, 293-302.

Hewlings, S.J., Kalman, D.S. 2017. Curcumin: A Review of its' effect on human health. Foods, 6(92), 1-11.

Jovicic, D., Jozinovic, A., Aleksovska, Grcevic, M., Subaric, D. 2017. Nutritional and health benefits of curcumin. J. Nutr. Diet, 6, 22-27.

Nirmala, T.V., Redya, D., Sree, E.K., Subbaiah, K.V., Raju, G.S., Reddy, R.V.S.K. 2018. Salmonellosis in poultry: A case report. Int. J. Curr. Microbiol. App. Sci., 7, 2347-2349.

Office International des Epizooties (OIE). 2012. Fowl Typoid and Pullorum Disease. OIE Terrestrial Manual Office International des Epizooties. Paris. France. https://www.oie.int/doc/ged/d7709.pdf.

Purnomo, D., Sugiharto, Isroil. 2015. Total Leukosit dan Diferensial Leukosit Darah Ayam Broiler Akibat Penggunaan Tepung 
Onggok Fermentasi Rhizopus oryzae Pada Ransum. JIIP., 25(3), 59-68.

Purwanti, S., Zuprizal, Yuwanta, T., Supadmo. 2014. In Vitro study of antibacterial activity of combination of water extract of turmeric and garlic. Int. J. Pharm. Life Sci., 5, 35803584 .

Rahman, M.M., Mazid, S.A., Hasan, M.K., Rony Z.I., Amin, M.M., Rahman, M.T. 2016. Immunogenicity of Salmonella pullorum killed vaccine in selected breeder flock. Int. J. Nat. Soc. Sci., 3, 01-04.

Revolledo, L. 2012. Avian Salmonellosis, vaccines and immune mechanisms of protection:present and future perspectives. World's Poultry Congress. http://www.facta.org.br/wpc2012 cd/pdfs/plenary/Liliana_Revolledo.pdf.

Rustam, E., Atmasari, I., Yanwirasti. 2007. Efek Antiinflamasi Ekstrak Etanol Kunyit (Curcuma domestica Val.) Pada Tikus putih Jantan Galur Wistar. Jurnal Sains dan Teknologi Farmasi, 12, 112-115.
Selvam, A., Gunaseelan, L., Kumar, K.S., Sekar M. 2010. Assessment of carrier status of Salmonella pullorum and Gallinarum infection in healthy flocks. J. Vet. Anim. Sci., 6, 99-101.

Shahani, K., Swaminathan, S.K., Freeman, D., Blum, A., Ma, L., Panyam, J. 2010. Injectable sustained release microparticles of curcumin: a new concept for cancer chemoprevention. Cancer Res., 70, 44434452.

Widhowati, D., Hidayah, N., Yunani, R., Malia, M. 2017. Early study the potency of turmeric (Curcuma domestica Val.) as immunostimulator for layers chickens against avian influenza (AI)Vaccine.https://www.atlantispress.co $\mathrm{m} /$ proceedings/icpsuas 17/25891300.

Winarto, W.P. 2003. Khasiat dan Manfaat Kunyit. Jakarta: Agromedia Pustaka, Hal: $2-4$. 